\title{
THE IMPACT OF CONTENT MARKETING, INFLUENCERS, AND E-PROMOTION ON PURCHASE INTENTION
}

\author{
Ida Ayu Iswari Pidada ${ }^{a}$
}

Putu Gede Genta Taruna Suyasa ${ }^{b}$

Fakultas Ekonomi dan Bisnis Universitas Pendidikan Nasional Denpasar

Email: iaiswaripdd@gmail.coma; ${ }^{\text {a }}$ gentataruna8@gmail.com ${ }^{\text {b }}$

ARTICLE HISTORY

Received:

18 February 2021

Revised

01 June 2021

Accepted:

14 September 2021

Online available:

20 November 2021

Keywords:

content marketing,

influncer, e-promotion,

purchase intention

\section{ABSTRACT}

Introduction: This study aims to analyze the impact of content marketing, influencers, and e-promotion on purchase intention.

Methods: This research is conducted on the Instagram Social Media of Biang Denpasar Gallery with population of 1,040 customers and sample of 91 customers.

Results: The results of the study show that content marketing, influencers, and electronic promotions have positive and significant impact on purchase intention. E-Promotion or online promotion as an activity through internet media.

Conclusion and suggestion: The type of promotional media used will affect purchases at an online shop. E-Promotion has the highest and significant value. E-promotion can be improved by paying attention to the searchability indicator.

\section{INTRODUCTION}

The rapid development of technology today affects various aspects of life. One aspect that has changed is the communication media and information system. The development of technology and forms of communication media are something that cannot be prevented. The business owner must really think about the right strategy in dealing with competition so that his company can survive even though there are many threats from competitors with similar fashion business fields, the problem experienced by the gallery of biang is in the marketing section, namely the lack of promotion in marketing the products produced. This study aims to analyze how the gallery of biang in the current era with technological advances and the existence of social media such as Instagram can market their products better and has easier access so that purchase 
intention occurs by customers, in which the purchase intention from month to month is fluctuating.

Table 1

Transactions since January - December 2019

\begin{tabular}{c|c}
\hline Month & Amount \\
\hline January & 43 \\
February & 41 \\
March & 102 \\
April & 108 \\
May & 147 \\
June & 126 \\
July & 142 \\
August & 110 \\
September & 63 \\
October & 56 \\
November & 45 \\
December & 57 \\
\hline Total & 1040 \\
\hline
\end{tabular}

There is an increase in March, May and July, also experiences a drastic decline in September to November and rise again in December.

\section{LITERATURE REVIEW}

\section{Content marketing}

Content--marketing is a strategy of marketing where we plan, distribute, andcreate content that attracts the right target audience, and then drives them into customers.

Joe (2009) stated that the indicators of Content Marketing are as follows

1. content with relevant information, content with accurate information. Meaning the content that is created must be compatible or similar to the goods or services that you want to trade, the content presented must contain precise and accurate information so that consumers know the intention of the content.

2. content with valuable information.

3. the information contained in the content has effective benefits. It means consuments know the meaning of the content.

4. content with consistent information. The information provided in the content must be consistent, meaning that the information presented must be consistent, not distorted or changing. 
5. the information contained in the content is easy to understand. The information contained must be easily understood by various groups in order to make it easier to attract consumers.

\section{Influencer}

Brown and Hayes $(2008,65)$ stated that influencers are third parties who are significantly affect in shaping decisions on customer purchases. According to Lee quoted by Novi Tri Hariyanti (2018:143) the indicators of influencers are:

1. Information

Information is a collection of data and facts that are processed and then managed in such a way that it becomes something that is easy to understand and useful for the recipient.

2. Encouragement

It is an internal condition that able to arouse us to act.

3. Role

It is a dynamic aspect of a person's position,

4. Status

The state or position in relation to the surrounding community.

\section{E-promotion}

Kotler (2010:173)-said that sales promotion is a short-term motivation to help driving sales of a product and service.

Indicators of online promotion according to Nuseir, Arora, AlMasri \& Gharaibeh (2010) are as follows:

1. Ease of searching, because this promotion is based online so it is easier to find information using the internet.

2. Information from web content, the information comes from web content or social media platforms that are used.

3. About the product/service, the promotion that is conveyed or carried out must be about the goods or services being traded.

4. Effectiveness and fast, due to using internet media, the promotions that are carried out are more effective and efficient

\section{Purchase Intention}

Purchase intention according to Basu Swastha (1993) is to identify all options to solve problems and assess options systematically and objectively. Goals that determine the strengths and weaknesses of each.

According to Rahman et al purchase intention can be measured using the following indicators: 
1. Willingness by consumers who make purchases. Namely the emergence of a desire to make purchases of the products and services.

2. The desire by consumers to make purchases in the future, namely the reemergence of the intention to repurchase products or services in the future.

3. The desire of consumers to make repeat purchases.

\section{RESEARCH METHODS}

This research is conducted on business owner who uses social media Instagram in Denpasar City, Bali. The population in this study is 1,040 and the sample in this study is 91 people. Data collection techniques uses interviews, and by using an instrument in the form of a questionnaire. The data analysis technique uses classical assumption test, multiple linear regression test, coefficient of determination test, $f$ test and $t$ test.

\section{RESULT AND ANALYSIS}

Table 2

Multiple Linear Regression

\begin{tabular}{|c|c|c|c|c|c|c|}
\hline \multicolumn{7}{|c|}{ Coefficients ${ }^{a}$} \\
\hline \multirow{2}{*}{\multicolumn{2}{|c|}{ Model }} & \multicolumn{2}{|c|}{$\begin{array}{l}\text { Unstandardized } \\
\text { Coefficients }\end{array}$} & $\begin{array}{l}\text { Standardi } \\
\text { zed } \\
\text { Coefficient } \\
\text { s }\end{array}$ & \multirow[b]{2}{*}{$t$} & \multirow[b]{2}{*}{ Sig. } \\
\hline & & B & $\begin{array}{l}\text { Std. } \\
\text { Error }\end{array}$ & Beta & & \\
\hline \multirow[t]{4}{*}{1} & (Constant) & 3.966 & .773 & & 5.132 & .000 \\
\hline & Content Marketing & .096 & .032 & .275 & 2.988 & .004 \\
\hline & \begin{tabular}{|l|l} 
Influencer \\
\end{tabular} & .148 & .067 & .229 & 2.203 & .030 \\
\hline & $\begin{array}{l}\text { E-Promotion } \\
\text { (Promosi Online) }\end{array}$ & .193 & .050 & .359 & 3.884 & .000 \\
\hline
\end{tabular}

Based on the result of the calculations in table 1 , it can be seen that the values of constant $a$, regression coefficients b1, b2, and b3 are as follows:
$a=3,966$
$b_{1}=0,096$
$b_{2}=0,148$
$b_{3}=0,193$ 
Table 3

Simultaneous Test Results (F-Test)

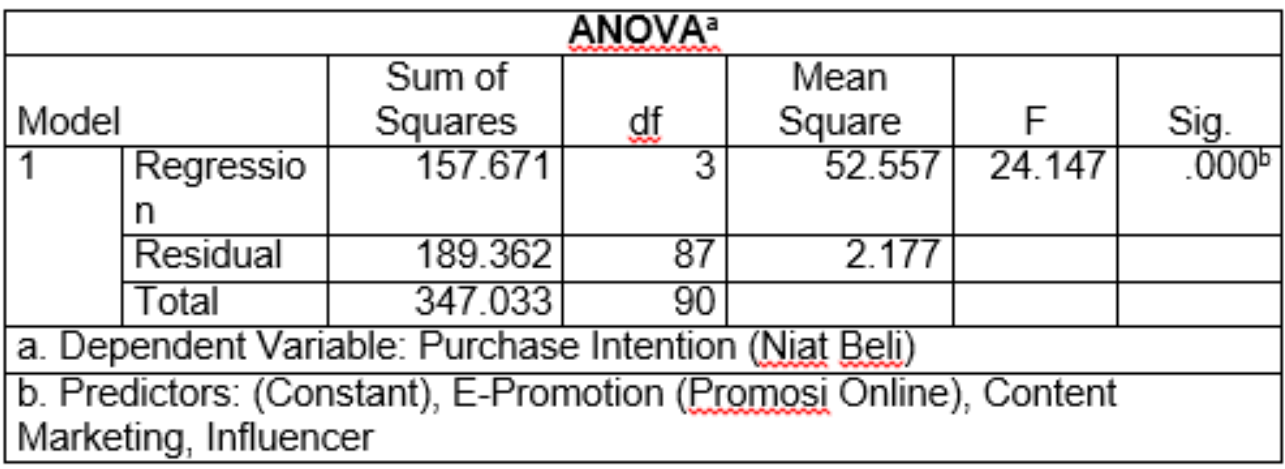

Based on the result of data processing in Table 2, it is known that the calculated $F$ value is 24,147 with an $F$ significance of $0.000<0.05$.

Table 4

Partial Test Results (t-Test)

\begin{tabular}{|l|r|r|c|}
\hline \multicolumn{1}{|c|}{ Variabel } & $\begin{array}{c}\text { Unstandardized } \\
\text { Coefficients Beta }\end{array}$ & t & Sig. \\
\hline Content marketing $\left(\mathrm{X}_{1}\right)$ & 0,096 & 2,988 & 0,004 \\
\hline Influencer $\left(\mathrm{X}_{2}\right)$ & 0,148 & 2,203 & 0,030 \\
\hline E-promotion $\left(\mathrm{X}_{3}\right)$ & 0,193 & 3,884 & 0,000 \\
\hline
\end{tabular}

a. Content marketing (X1) has positive impact on purchase intention (Y). This result is indicated by a positive regression coefficient of 0.096 with $t$ statistic $=2.988$ and significance $(p)=0.004<0.05$.

b. Influencer $(\mathrm{X} 2)$ has a positive impact on purchase intention (Y). This result is indicated by a positive regression coefficient of 0.148 with t-statistic $=$ 2.203 and significance $(p)=0.030<0.05$.

c. E-promotion (X3) has a positive impact on purchase intention (Y). This result is indicated by a positive regression coefficient of 0.193 with $t$ statistic $=3.884$ and significance $(p)=0.000<0.05$.

\section{ANALYSIS}

The better the content marketing, the higher the purchase intention on the Gallery of Biang Denpasar Social Media Instagram. Vice versa, the worse the content marketing, the lower the purchase intention on the Social Media Instagram Gallery of Biang Denpasar. This is in line with the phenomenon that occurs in the Gallery of Biang Denpasar Social Media Instagram which shows a decrease in purchase intention due to lack of content marketing factors, it is seen from the phenomenon that occurs regarding content with consistent information, where the Gallery of Biang Denpasar Social Media Instagram should be more consistent on providing information to consumers. 
The better the influencer, the more purchase intention on Social Media Instragram Gallery of Biang Denpasar will increase. Vice versa, the worse the influencer does, the lower the purchase intention on Social Media Instragram Gallery of Biang Denpasar. This is in line with the phenomenon that occurs in the Social Media Instragram Gallery of Biang Denpasar which shows a decrease in purchase intention due to the lack of influencer factors seen from the phenomenon that occurs regarding information, where Social Media Instagram Gallery of Biang Denpasar must be able to provide accurate information to consumers.

The better the e-promotion, the more purchase intention will be on Social Media Instagram Gallery of Biang Denpasar. Vice versa, the worse the e-promotion carried out, the lower the purchase intention on the Social Media Instagram Gallery of Biang Denpasar. This is in line with the phenomenon that occurs in the Social Media Instagram Gallery of Biang Denpasar which shows a decrease in purchase intention due to the lack of e-promotion factors seen from the phenomenon of the ease of search, Social Media Instagram Gallery of Biang Denpasar should be able to make it easier for consumers to find a product which they want to purchase so that purchase intention will increase.

The better the influencer and the e-promotion, the purchase intention will be increased on the Social Media Instagram Gallery of Biang Denpasar. This is in line with the phenomenon that occurred in the Social Media Instagram Gallery of Biang Denpasar which shows a decrease in purchase intention due to the lack factors such as content marketing, influencers, and e-promotion seen from the phenomenon of the lack of consumer desire to make purchases in the future, where Social Media Instagram Gallery of Biang Denpasar must be able to update the products on sale so that purchase intention will increase.

\section{CONCLUSION}

Content marketing, Influencer, E-promotion partially have a positive and significant impact on purchase intention on Social Media Instagram Gallery of Biang Denpasar. Content marketing, influencers and e-promotion simultaneously or together have a positive and significant impact on purchase intention on Social Media Instagram Gallery of Biang Denpasar.

It is recommended for companies to continue on increasing these three factors and paying attention to other factors related to increasing purchase intention. Further researchers are advised to increase the number of samples and variables, as well as to conduct research in different companies and the addition of mediating variables.

Published by University of Airlangga.

This is an open access article under the CC BY SA license (https://creativecommons.org/licenses/by-sa/4.0/) 


\section{REFERENCES}

Brown, D. \& Hayes, N. (2008). Influencer Marketing Who Really Influences Your Customers?. Oxford : ButterworthHeinemaan

Hariyanti, N. T., \& Wirapraja, A. (2018). Pengaruh dari nfluencer Marketing Sebagai Strategi Pemasaran Digital Era Moderen (Sebuah Studi Literatur). Jurnal Eksekutif, 15 (1), 133-146.

Joe, P. (2009). What Is Content Marketing? Diambil kembali dari Content Marketing Institute: https://contentmarketinginstitute.com/ what-is-content-marketing/

Kotler, Philip (2006). Prinsip - prinsip Pemasaran Manajemen. Jakarta : Prenhalindo

Kotler, P. \& Keller, K.L. (2012). Marketing Management 14E. New Jersey: Pearson.

Kotler, P., (2000). Marketing Management. The Millenium Edition. NJ: Pearson Prentice Hall.

Kotler, Philip. 2010. Manajemen Pemasaran. Jakarta : Erlangga

Nuseir, Arora, Al-Masri \& Gharaibeh.2010. Bukti Belanja Online : Sebuah Perspektif Konsumen

Rahman, M. S., Haque, M., \& Khan, A. H. (2012). A conceptual study on consumers puchaseintention of broadband services. service quality and experience economyperspective. International Journal Busines And Management, 7(18), 115-129

Swastha, Basu. Manajemen Penjualan. Edisi Ketiga. Yogyakarta : BPFE. 